\title{
Peace to Prosperity Plan as a one State Solution
}

\author{
Ahmad Kilani ${ }^{1}$, Mohammad Ali Alawieh ${ }^{2}$, Mussaui-Ulianishcheva E. V. ${ }^{3}$ \& Ulyanishcheva L. V. ${ }^{4}$ \\ 1 Department of Comparative Politics, RUDN, Moscow, Russia \\ ${ }^{2}$ RUDN, Moscow, Russia \\ ${ }^{3}$ Department of Foreign Languages, RUDN, Moscow, Russia \\ ${ }^{4}$ Faculty of Philology, RUDN, Moscow, Russia \\ Correspondence: Ahmad Kilani, Department of Comparative Politics, RUDN, Moscow, Russia. E-mail: \\ ahmad.kilanys@gmail.com
}

Received: March 23, 2020

Accepted: May 7, $2020 \quad$ Online Published: May 25, 2020

doi:10.5539/jpl.v13n2p94

URL: https://doi.org/10.5539/jpl.v13n2p94

\begin{abstract}
After almost twenty-five years since the Oslo accords, the last relatively successful peace agreement between the Palestinians and the Israelis, Trump's plan is the newest attempt to achieve sustainable long-lasting peace in the Middle East between the two conflicting parties. This paper argues that the P\&P plan is designed to a one-state solution. Through a comparison between the Oslo Accords and the P\&P plan we can observe the shift from the two state notions to the one state concept with a system of apartheid. The article also attempts to suggest improvements on the plan to be more suitable for both parties under a one state solution, namely, to include a new constitution.
\end{abstract}

Keywords: Israel, Palestine, USA, Oslo Accords, Peace to Prosperity, Trump

\section{Introduction}

Notwithstanding of Israel's upcoming elections with a prime minister facing trial for corruption, an American president reelection campaign in less than a year while his impeachment trial is ongoing and Palestinians who had not spoken to America in two years, Donald Trump has unveiled his long-awaited Middle East peace plan. His vision presented a match to the Israeli leader's hard-line, nationalist views while falling far short of Palestinian goals. Trump's plan foresees a fragmented Palestinian state that turns over key parts of the West Bank to Israel. It sides with Israel on key quarrelsome matters that have bedeviled past peace determinations, including borders, the status of Jerusalem and Jewish settlements, and assigns almost impossible settings for granting the Palestinians their ambitious state.

The plan permits Israel to annex much of the occupied West Bank immediately, offering the Palestinians only local control in isolated Bantustans surrounded by Israeli territory. Netanyahu said that the Palestinians would be required to recognize Israel as a Jewish state, cede the entire Jordan Valley, disarm Hamas, and abandon hope for both the return of refugees who fled homes in what is now Israel and for a capital in Jerusalem's Old City. The plan sets out constraints that are difficult for Palestinians to accept, and meritoriously offers Israel with a blueprint to withstand the one-state reality that exists in real life. The plan was considered by many Israeli, Palestinians and International rights activists as an apartheid plan to separate the Palestinians into enclaves.

The Palestinians are seeking all of the West Bank and east Jerusalem - areas captured by Israel in the 1967 Mideast war - for an independent state and the removal of many of 500,000 to 700,000 Israeli settlers from these areas. Saeb Erekat, the Palestinian chief negotiator in the Oslo Accord, stated in an interview with RT Arabic that Trump's plan is "100 percent the ideas I personally heard many times from Netanyahu and his negotiators. I can assure you that the American so-called peace team have only copied and pasted Netanyahu's and the settlers' councils plan." The plan was refused by the Palestinian authorities before even going public.

In this paper we argue that Trump's plan swerved from the typical historical peace negotiations between the Israelis and the Palestinians. Although the plan follows a realistic approach to the current political situation, nevertheless, it lacks the consent of the Arabs. Even though some Ambassadors of Arab states were present during the plan announcement and some of these countries unofficially consent with the plan, nevertheless, it would lead to a political recklessness to publicly support it. The paper considers that this plan is applicable under 
a one state solution and suggests adjustments to be more satisfactory for both parties. Henceforth, the paper compares the Oslo Accords and the Peace to Prosperity plan to show how the peace progress negotiations are shifting towards a one-state solution due to new realities in the region.

To compare both documents, the paper revises the Oslo Accords through its three phases from the archive and examine what was expected, what was implemented what were the results. Then, the article revises the peace to prosperity plan emphasizing on why it was created in this manner and examine its reality. Finally, the article provides suggestions and adjustment to improve the plan to be acceptable for both parties.

\section{Oslo Accords}

The Oslo Accords were a set of agreements between the state of Israel and the Palestine Liberation Organization (PLO) which were signed between the years 1993 and 1995 in Washington DC and Egypt respectively. The aim of the accords was to initiate a peace agreement between the two parties and to achieve the self-determination rights for the Palestinians. Numerous agreements were achieved in this process; however, it was terminated after the failure of additional settlements between both parties and the launch of the Second Intifada. These accords can be categorized into three main agreements:

1) The Declaration of Principles (DOP) (Knesset, 1993), the Oslo Agreement, was signed in Washington DC on the $13^{\text {th }}$ of September 1993. It gives the overall plans for the parleys to come and sets the basics for a regime of Palestinian self-government in the West Bank and Gaza for a provisional period of five years. After this period, a perpetual agreement established on Security Council Resolutions 242 and 338 must enter into execution. This agreement is intended to deal not only with the long-lasting juridical procedure of the Palestinian body but also with Jerusalem, Israeli settlements, global security arrangements, borders, refugees and other difficulties of mutual benefits in future agreements.

2) The Gaza-Jericho Autonomy Agreement, Cairo Agreement or Oslo one Agreement (Israel Ministry of Foreign Affairs, 1994), was signed on the $4^{\text {th }}$ of May 1994. The agreement was the first stage of Palestinian self-government. The Israeli military redeployment headed by the establishment of the Palestinian National Authority (PNA) dedicated to partial civil and security controls. Based on the agreement of the DOP the provisional period initiates with the Israeli military repositioning from Gaza and Jericho. Israel keeps its control of the settlements and military locations. This interim deadline was supposed to end five years from its date of signature.

3) The Interim Agreement on the West Bank and the Gaza Strip, Taba Agreement or Oslo two Agreement (Knesset, 1995), was settled in Taba on the $26^{\text {th }}$ of September 1995 and signed in Washington on the 28th. It is the second stage of Palestinian self-government. This agreement dealt with two main clauses:

A. Dividing the West Bank into three Zones: Area A includes territories already occupied in May 1994 and the six major cities of the Palestinian territories. Hebron has a special status and is subject to a distinct arrangement. There is full Palestinian civil jurisdiction and internal security also is in Palestinian hands. Area B encompasses other Arab populated areas of the West Bank. There is a full Palestinian civilian authority, but interior security is under a shared Israeli-Palestinian command. Area C covers Israeli settlements, barracks, state lands and infrastructures. It remains under Israeli civil and overall security control. Conversely, there is a partial Palestinian civil jurisdiction. Areas A and B comprises $7.6 \%$ and $21.4 \%$ respectively of the West Bank and Gaza and cover more than $90 \%$ of the local Palestinian inhabitants. Israeli Civil management has been parted and Israeli military forces redistributed. Israel nevertheless retains complete governance over external security. Area $\mathrm{C}$ covers $71 \%$ of the Palestinian territories. Israeli military redeployments from some parts of Area $\mathrm{C}$ were expected at six-monthly intermissions, for 18 months, after the initiation of the Autonomy Council.

B. Election of a Palestinian Legislative Council (PLC): Elections were held on 20 January 1996. The Palestinian Legislative Council and its executive appointed committee, the Palestinian National Authority (PNA), exercise civil powers. All regulation and acts of these Palestinian institutions are inevitably conveyed to the Israeli authorities for control.

\section{The Expectations, Implementations, and Results}

Many observers considered that the Oslo Accords have failed since the agreements did not meet the expectation of both parties. For Israeli expectations, it is mostly focused on security. Years of Palestinian violence had steered many Israelis to panic from abandoning their supremacy over the West Bank and Gaza Strip thus leave Israel unprotected to aggressive Palestinian militias who would use the lands as foundations from which to initiate violent acts well inside Israel. The Oslo agreements were to lessen these qualms by founding a Palestinian Authority that would consider militias such as Hamas and Islamic Jihad as a menace to its own 
presence, consequently siding Israel's concerns in fighting violence with the concerns of the Palestinian leadership.

Palestinian expectations were in two main parts. The first expectation was that the Oslo process had to carry a termination to the construction and development of Israeli settlements in the West Bank and the Gaza Strip. The second expectation concentrated on better economic development in Palestinian society, enlivening Palestinians out of devastating poverty and tapering the gap of the living standards between them and their neighbors.

The implementation of the Oslo agreements initially went fine. The first Israeli relocation from Palestinian lands in the Gaza Strip and in Jericho on the West Bank was performed efficiently. The formation of the Palestinian Authority and Yasser Arafat's appointment as the President came after. However, the positive attitude of building confidence in both the Israelis and Palestinians was brief, as each side started to accuse the other of breaching its commitment.

Palestinians frequently clarified that the failure of the Oslo peace process was because of the ongoing development of Israeli settlements and the unsatisfactory portion of the territorial governance of the Palestinian Authority. Palestinians understood that the Oslo agreements comprised a firm Israeli assurance to stop the increase of settlements building and even begin disassembling them. While there was no such clear obligation in the signed accords, Palestinians uphold that this must have been assumed by the Israelis as completely self-evident, and that such circumstances would be an essential requirement for a Palestinian agreement to any bargain.

In addition, a free passage route linking the West Bank and Gaza Strip passing through Israeli lands was never achieved, but Israeli military barricades were constructed on the roads between Palestinian towns. While Israelis considered these measurements under security concerns, these actions were understood by the Palestinians as an Israeli effort to make detached Palestinian enclaves without linked territorial borders, in order to prevent any likelihood of a practical future Palestinian state. It was seen by the Palestinians as an ultimate Israeli treachery demonstrating that Israel never planned to settle to a peace treaty.

From an Israeli standpoint, the delicacies of Israeli-Palestinian relations since the establishing of the Oslo Accords set their vilest doubts that the Oslo process would give militant groups the instruments and the territories for ferocious violent attacks against Israelis. A clear example can be given is Hamas's control over Gaza strip and launching numerous rockets against Israel.

As most experts considered that the Oslo Agreements ultimately failed due to the mutual mistrust and unfulfilled expectation, nevertheless, the Accords succeeded in achieving mutual recognition between the conflicting parties as a first keystone of any future peace negotiations. The main complications for the Palestinians were the continuation of building illegal settlements and for the Israelis were the continuous security threats. The Palestinians mainly accepted these accords since it neglected main issues such as the status of Jerusalem, and refugees' right to return. These issues were discussed profoundly under Trump's plan.

\section{Peace for Prosperity Plan (P\&P)}

The 181 pages of the P\&P plan is divided into two parts, part A which is political framework, and part B which is economic framework. In this paper we will only discuss the political framework of the plan and will discuss section four, the borders, section five, Jerusalem, and section sixteen, the refugees (The White House, 2020). These sections are the core of the conflict between the Palestinians and the Israelis, and they were not deliberated in the Oslo Accords.

Section Four: The plan acknowledges Palestinian rights to approximately $70 \%$ of the West Bank. The plan suggested land exchanges, but dismissed the idea of fair land exchanges, claiming that Palestinians should not receive all the lands of pre-1967, but offered lands that would be sensibly like pre-1967 lands. In return for Israel seizing shares of the West Bank, the Palestinians would receive portions of the Negev Desert; these parts in the Negev would be detached from much of the Palestinian main territories. The Trump plan gives Palestinians fewer lands than preceding agreements.

The plan provides an Israeli claim to the whole Jordan Valley. Israel considers the valley as militarily important. Palestinians consider the valley as vital for agriculture. The valley also lets Palestinians access to the Jordan River, which waters 80,000 hectares of agricultural territories in the West Bank; annexing the valley to Israel would permit it to divert the water for its own utilization. Within the West Bank, approximately $97 \%$ of Palestinians would be combined into adjoining Palestinian territory and $97 \%$ of Israelis into adjoining Israeli territory.

The employment of the plan is provisional, being conditioned to the Gaza Criteria and would only continue if the 
control of the Gaza Strip, currently managed by Hamas, were transported back either to the Palestinian Authority or another Palestinian body Israel agrees of. The plan calls for Hamas, PIJ, and all other militias in Gaza to be neutralized and to make Gaza fully demilitarized. In addition, Hamas should pledge to the track of peace with the State of Israel by accepting the Quartet principles, which include definitely and ultimate recognizing the State of Israel, pledging to pacifism, and be compliant to preceding settlements and responsibilities between the parties, containing the disarming of all militant groups.

Section Five: The plan confirms Israel has a right to the whole of an undivided Jerusalem, identifying it as Israel's capital. The plan does allow a Palestinian capital for a future State of Palestine to be situated outside, and east and north of, the Separation Barrier, in that part of East Jerusalem surrounding Kafr 'Aqab, and the eastern refugee camp of Shuafat and Abu Dis. It would hold whatever name Palestinians decide to call it, perhaps al Quds, which is the Arabic translation of Jerusalem. The plan puts the Temple Mount, with Al-Aqsa mosque, under Israeli control. The plan confirms the present reality of the status quo to be preserved; thus, the plan discards Palestinian privileges to Haram al-Sharif. The plan gives Israel the duty of protecting the Holy Sites and assuring freedom of worship.

Section Sixteen: Palestinian refugees are deprived of the right to return, not only to Israel, but to the Palestinian future state unless Israel allows, thus most will be required to stay where they are. The plan states that "Their Arab brothers have the moral responsibility to integrate them into their countries as the Jews were integrated into the State of Israel". Upon the approval of the agreement as proposed under Trump's Middle East plan, Palestinian refugee status would cease to exist and the United Nation's agency for Palestinian refugees would be dismissed. Refugees who escaped the wars in 1948 and 1967 would be given some sort of reimbursement, yet not even a figurative number would be permissible to return to their lands.

Trump's plan can be considered as a historical event that crossed all the red lines that were set during previous peace negotiations. Jerusalem, the refugees' right to return and the Israelis illegal settlement in the west bank were made first priority in the peace plan on contrary of the Oslo Accords which always avoided such sensitive issues. The plan was considered by many experts as dead before birth due to its similarity with the South African apartheid model of creating enclaves for the Palestinians and not a state. Internationally, the plan was criticized by the EU, the UN, the Arab league, and even by some Israeli media and rights activities.

The plan was well set from a realist approach. This reality was presented as a two-state solution in its naming but a one-state solution in its essence. The west bank holds a vast number of illegal settlers, between 500,000 and 700,000 which are not feasible to be relocated from their illegal settlements since it is an economic burden and will face strong opposition by the far-right Jewish communities. Also, the refugee return rights were seen by Israelis as a shift of balance in term of population and by granting the right for Palestinians in Arab countries to return to the future Palestinian state or Israel would create a political change in the demographics. The plan has well considered the security of Israel and made it at its core without considering any rights for the Palestinians to acquire a standard state. This can be seen through the annexation of the Jordan valley by Israel, their full control over the future borders of the future Palestine state, and the demand for a demilitarized state.

\section{The New Reality of the P\&P: One State Solution}

The creation of two-state solution has subjugated negotiations of the Palestinian-Israeli struggle. However, the notion of two countries for two nations in such a land was constantly far from feasibility, and recently, certainty has exhibited the death of this solution. It never proposed a realistic route. This paper is proposing a better outcome for all interested parties carrying long-lasting peace: prosperity, security and equivalent privileges for Palestinians and Israelis in a one state shared.

It has been conceivable to notice this one-state solution formulated even before Trump's plan. The Obama administration attempted to save the peace process, and reflected that previous solution had a short period left before it would not be practical (Remnick, 2016). Resolution 2334, which the UN Security Council issued with U.S. consent in late 2016, known as "salvaging the two-state solution" by requesting several phases, with an instant end to Israeli illegal settlement construction in the occupied territories (UNSC, 2016).

Trump's policies placed the final nail in the coffin of the two-state solution with numerous notions that he prefers the one-state approach (Tamkin, 2017). The paper noticed a genuine shift in the current stage of the peace process. From the early 1990s, no U.S. president had ever before publicly proposed accepting a one-state solution. Trump's policies became more vibrant in the years that have followed, as he and his administration have approved a right-wing Israeli demand intended at a one-state product. A state that will preserve Israeli supremacy over Palestinian subjects and by not granting the Palestinians equal rights. Evident examples can be seen in recognizing Jerusalem as the capital of Israel by moving the US embassy there, and by supporting the 
illegal settlements building in the West Bank even before the plan announcement.

Under Prime Minister Benjamin Netanyahu, Israel has ignored any effort in seeking a two-state idea, and support for such solution within Israelis communities has progressively diminished whereas Palestinians continue to pursue a separate state. However, after years of disappointment and obstruction, most Palestinians no longer consider that path as feasible either. Over the years, the Israelis maintained enough power and cultured enough support from the US to permit them to inhabit and grasp the territories and to produce a one-state realm of their own formula: A one state with an Israeli population and a discriminated Palestinian population living in cantons. Netanyahu and Trump are pursuing not to alter the status quo yet to endorse a one state that adhesives de facto apartheid in which Palestinians are deprived of basic rights.

Before the Israeli election in 2019, Netanyahu stated that he is planning to annex the Jordan Valley and to legalize all Israeli settlements in the West Bank (BBC, 2019) which would swallow up to 60 percent of the West Bank and leave the other 40 percent as isolated cantons, unconnected to one another. Currently, many Israelis are in favor of keeping much of the occupied territories endlessly. Netanyahu's announcement was extremely remarkable as the idea of annexation for the Israelis is not a controversial topic. A recent poll conducted by Haaretz showed that 42 percent of the Israelis support the annexation and only 28 percent opposed it (Kraft, 2019).

Palestinian leaders also made blunders that abridged the probabilities for a practical two-state solution, namely the Oslo Accords. They have acquiesced to a plan that reinvigorated Israel's enlargement, abandoned their aptitude to encounter it, and suspended the international community support. Under Oslo, the Palestinians relied on the United States to mediate an agreement with Israel, a state that American leaders adore as a strong lobby for their election campaigns and have never been able to congress without their consent in most cases. As the peace process did not meet expectations, Palestinians revolted against the occupation, sometimes violently as it was called the "intifada". Israel referred to those responses to validate additional subjugation.

As the Oslo process has pulled over, the validity of the two-state solution is put into questioning. The problem is in the Israel dilemma. Israel likes to consider itself a democracy even as it rules over millions of subjects denied basic political rights. Infinite negotiations have only buried that vital fact. Constructive progress in the peace talks would intimidate Jewish supremacy of the land, something that has proved more imperative to Israel than democracy. That is why the Israelis have preferred Oslo-type negotiations, which make it seem they are sincerely attempting to deal with the Palestinian concern but never force them to truly give up concrete claims such as dividing Jerusalem, halting the illegal settlements building, grating rights for refugees to return and ultimately create a Palestinian independent state.

Nevertheless, The Palestinian authority has dedicated itself to the two-state idea, even with a state that fall far short of minimal Palestinian needs. Such a state would not permit Palestinian refugees to return to their ancestral towns and cities, or provide full equality to Palestinian citizens of Israel, or grant Palestinians honest independence and authority over their lands. The paper proposes for the Palestinian to disregard its promotion of a two-state idea, and to acknowledge the reality that there is and always will be only one state and concentrate their struggles on making that state a sustainable home for all of the land's populations, Jews and Arabs alike.

It can be argued that such a swing in policy would weaken the hard-won agreements, entrenched in decades of engagement and international law, that the Palestinians have a right to their own country. Those agreements, nevertheless, did not produce much for the Palestinians. Numerous UN resolutions have failed to halt Israeli settlements or gain Palestinians an independent state, so they wouldn't be losing much. In a one-state idea, Palestinians shall gain full equality under the law, so they would be achieving a great progress.

Israelis would also profit from an alteration to such a country. They would achieve security, stability, and development in addition to escaping international and regional alienation and drawing back the ethical decay that the occupation has shaped the Israeli society. In addition, they would uphold networks to religious and historical locations in the current Palestinian territories. Although many Israelis would prefer to continue the current situation. Nonetheless, Israel cannot keep repudiating the human rights of masses of people indeterminately and pretend to continue to be an ordinary member of the international community. The current apartheid system will ultimately be renowned for what it is, and then Israel's proper choices will be clear: change to one-state country with equivalent human rights for all citizens or become an isolated country infamous for its oppression.

Trump will never accept the notion of equal human rights for all citizens, namely the Palestinians. However, American voters would. A survey made last year by the University of Maryland observed that Americans were almost equally divided between supporting a two-state solution and supporting a one-state solution with equal civil rights for all citizens. Nevertheless, when they were asked what they preferred if a two-state solution was 
not possible, the current situation or one state with equal civil rights, they selected the last by a two-to-one margin (Kyser, 2018). This would allow for a future administration to project the aspirations of the American people.

\section{Suggestions and Adjustments to the P\&P}

Supporters of equal rights need to take necessary paces to produce a certainty that the one-state solution does not become as void as the other solution. To emphasis and execute this solution, the plan must consequently suggest not only a new state for the Palestinians instead a new constitution for Israel. This ought to validate their vow to democracy. Instead of that legal hodgepodge, which has been utilized to safeguard the privileges of some and to reject the human rights of others, Israelis and Palestinians ought to put effort together to create a constitution that would sustain the civil rights for everyone. The innovative constitution should identify that the state will be a land to both nations and that, notwithstanding domestic accounts and expressions on either side that claim the opposite, both nations have ancient bonds to the territory. It would concede the Jewish people's past of being mistreated and the supreme prominence of safeguarding that all citizens, irrespective of ethnicity, religion or nationality, have a right to protection and safety. Also, it would acknowledge the injustices done to Palestinians and initiate a procedure to recompense them.

A innovative constitution might provide nationality to all the individuals presently living in these territories and generate paths for migrants from other places to neutralization. All inhabitants shall receive total political and civil privileges, with the liberty of movement, speech, equality before the law, and practicing religion. The country would be prohibited from discerning on the background of culture, religion or ethnicity. For such a state to succeed, these constitutional values should be deliberated as introductory, and an immense bar for amendment must be achieved; for instance, a unanimous consent in the legislative branch on crucial matters shall be met before any changes. This should safeguard the human rights and could not be changed by a modest majority and forbid any group from using a demographic gain to modify the characteristics of the new system.

An alteration to a fresh state with equivalent privileges should necessitate a sort of mutual trust that cannot be constructed as there is acts of coercion, ferocity, and carnage. Hence the new system should also need a reconciliation process engrossed on uplifting justice. This new model can examine past efforts such as in South Africa and Rwanda.

As the plan should be oriented towards a one state solution with Israeli supremacy, it's the upcoming American administration responsibility to push on the Israelis to provide more rights to the Palestinians without endangering their own existence. For instance, Israel's northern neighbor, Lebanon, have had a consensual democracy that divide authority between different sects. Israel could provide such a similar model where it can keep the prime minister position in its hand with most of the powers, and give the presidency to Palestinians. Israel should exclude Gaza from the one state solution due to two main reasons: create a balancing demography and isolating Hamas which threaten Israel's security.

A one state solution precisely aligns itself with Trump's plan. It would keep Jerusalem under Israel's control, safeguard the settlements in the west bank, give the refugees the right to return under specific control of not overwhelming the demographic balance and lower the security threat in the west bank. The P\&P plan should halt from referring to the alleged Palestinian state and instead deal with the reality that the plan is designed for a one-state solution with depriving the Palestinians from most of their rights. Henceforth, the only viable adjustment is to provide equal rights for all the people living in these territories through a new constitution.

\section{Conclusion}

The Oslo Accords, under American mediation, were peace talks that achieved a set of agreements under the two-state solution notion which ultimately failed due to mistrust from both sides. The Israelis had security concerns and the Palestinians were hoping to create an independent state. Trump's plan came as a facilitator instead of a mediator. In these terms the American administration pushed the Israeli agenda under ambiguous policies that were rejected by the international community. For instance, the plan proposed a future Palestinian state; nevertheless, it did not provide some characteristics of an independent state such as accepting the return of the refugees, raising an armed force, and conducting relations with other nations. The plan was mainly concerned with Israel's security only. Instead of creating a Palestinian state, the plan proposed an answer closer to a one state solution with an apartheid system for the Palestinians.

The paper deliberates the current problem is within Israel itself since they gained the supremacy over the Palestinians. Hence, the paper proposes an adjustment for the Trump's plan and to make it more egalitarian; a one state solution that would be fair to both conflicting party; a solution that Israel must initiate to guarantee its 
long-lasting security which is considered its first priority. A one state solution can assimilate both nations into one hybrid state under a new constitution with certain consensual policies that would guarantee the continuous Israeli existence but giving the Palestinians their full rights.

\section{References}

BBC. (2019, September 10). Israel PM Netanyahu vows to annex occupied Jordan Valley. Retrieved January 23, 2020, from https://www.bbc.com/news/world-middle-east-49655226

Israel Ministry of Foreign Affairs. (1994, May 04). Agreement on Gaza Strip and Jericho Area. Retrieved January 20, 2020, from https://mfa.gov.il/mfa/foreignpolicy/peace/guide/pages/agreement\%20on\%20gaza\%20strip\%20and\%20jeri cho\%20area.aspx

Knesset. (1993, September 13). Declaration of Principles on Interim Self-Government Arrangements. Retrieved January 10, 2020, from https://web.archive.org/web/20021115183950/http:/knesset.gov.il/process/docs/oslo_eng.htm

Knesset. (1995, September 28). Israeli-Palestinian Interim Agreement on the West Bank and the Gaza Strip. Retrieved January 23, 2020, from https://web.archive.org/web/20021115180646/http:/knesset.gov.il/process/docs/heskemb_eng.htm

Kraft, D. (2019, March 25). Haaretz Poll: 42\% of Israelis Back West Bank Annexation, Including Two-state $\begin{array}{lllll}\text { Supporters. } & \text { Retrieved } & \text { January } & 2020, & \text { from }\end{array}$ https://www.haaretz.com/israel-news/israeli-palestinian-conflict-solutions/.premium-42-of-israelis-back-we st-bank-annexation-including-two-state-supporters-1.7047313

Kyser, B. (2018). UMD Critical Issues Poll Shows Growing U.S. Public Support of One-State Solution for Israeli-Palestinian Conflict. College Park: University of Maryland.

Remnick, D. (2016, Devember 28). The Obama Administration's Final WArning on the Middle EAst Peace Process. Retrieved $\quad$ February 1, 2020, from https://www.newyorker.com/news/news-desk/the-obama-administrations-final-warning-on-the-middle-eastpeace-process

Tamkin, E. (2017, February 15). One-State Solution, or Two? Trump's 'Happy With the One That Both Parties Like'. Retrieved $\quad$ February $\quad 15, \quad 2020, \quad$ from https://foreignpolicy.com/2017/02/15/903972-bibi-israel-palestinians-netanyahu/

The White House. (2020, January). Peace to Prosperity. Retrieved February 9, 2020, from https://www.whitehouse.gov/peacetoprosperity/

UNSC. (2016, December 23). Israel's Settlements Have No Legal Validity, Constitute Flagrant Violation of International Law, Security Council Reaffirms. Retrieved February 20, 2020, from https://www.un.org/press/en/2016/sc12657.doc.htm

\section{Copyrights}

Copyright for this article is retained by the author(s), with first publication rights granted to the journal.

This is an open-access article distributed under the terms and conditions of the Creative Commons Attribution license (http://creativecommons.org/licenses/by/4.0/). 